\title{
Interactive comment on "Highly active and stable fungal ice nuclei are widespread among Fusarium species" by Anna T. Kunert et al.
}

\section{Anonymous Referee \#1}

Received and published: 21 August 2019

\section{General comments}

The authors report on the ice nucleating ability of 112 strains from 65 different Fusarium species. Using standard, valid and well characterized drop freezing assays TINA and LINDA, the authors determined that $18 / 112$ of the tests strains showed initial freezing temperatures of -3.5 to $-11.2 \mathrm{oC}$ and that $7 / 65$ species had IN-"active" strains. The authors subsequently use some of the IN-active strains and submit them to physical processing by filtering and by refreezing the strains as well as to chemical processing by bubbling ozone and NO2 through the extract solution. Most of these processing experiments led to null results.

These results are certainly publishable, bring value to the field of bioaerosols and fit the scope of the journal. The manuscript can be accepted after the following comments

Printer-friendly version

Discussion paper 
have been addressed, and likely after changes are made to improve the discussion of the results, including further quantification, blank data, reproducibility discussion and additional references for the context of the work.

Specific comments

1. Title: The title is misleading: the authors' conclusion is that $16 \%$ of the tested strains were ice active above -14 oC. I would argue that this percentage does not equate to "widespread". The authors also did substantial work with physical and chemical processing of their material which is not reflected in the title, but could be. For example, something along the lines of "Ice nucleation ability of 65 different Fusarium species: Effects of storage, size and chemical processing"

2. Abstract Why did the authors choose $-14 \mathrm{oC}$ as their threshold? This discussion should be added here in the abstract (and in the text as well).

The relevance of Fusarium should be explained in the abstract.

3. Introduction Lines 16-17: more recent references should be added, especially because of the mention of macromolecules. Also see review by (Knopf et al., 2018).

Lines 18-20: it would be important to mention nonetheless that recent work has made contributions to our understanding of IN and precipitation references by (Petters and Wright, 2015; Stopelli et al., 2015, 2017).

Lines 21-23: the 3+9 references could be better represented by explaining what each one has observed in one or two sentences each. This added discussion could help set the stage for the relevance of the work under review.

Lines 24-26: same comment as above in addition to this reference (Šantl-Temkiv et al., 2015)

Lines 28-30: when temperatures are reported, what fraction does it represented? The onset? $1 \%$ ? Temperature when $50 \%$ of the droplets are frozen- T50? See (Vali, 2019)

Printer-friendly version

Discussion paper 
Line 39: define the positive selective pressure for IN activity

It would be useful for the authors to discuss the mode of freezing investigated and why immersion freezing was used and what is its relevance.

Good overview of bioprecipitation. Great description of the evolutionary reasons for fungal species to be good ice nuclei.

Interactive

comment

4. Materials and methods In general, controls and filter blanks are missing from the data description and analysis and the authors are encouraged to show this data (perhaps in supplementary information) and to discuss this data. For example, what was the IN activity of the water background? What was the activity of the filter background? How did the backgrounds differ from LINDA to TINA?

It is clear that the authors used two techniques for their experiments, yet their discussion does not include any comparison plots or discussing the differences in the two instruments. Each figure (and Table S1) should also state which instrument was used to acquire the data.

Line 115: could the authors show the positive control data?

Lines 119: clarification: can the authors show their calculations here and are the data presented corrected for the freezing point depression or is the $0.5 \mathrm{C}$ part of the overall uncertainty?

Additional experiment: dilution series of an active strain to see if the behaviour of the IN active material in solution is linear. I would argue that this experiment would be important to help support the seemingly accurate high freezing temperature data observed for certain strains, for example in Figures 3 and 4 and S1.

5. Results and discussion It is necessary for the authors to define their reported freezing temperatures. Are they the onset, the equivalent of one well freezing? If so, how do the authors address the recommendations of not using the onset addressed in (Polen et al., 2018)? Reporting freezing temperatures as T10 and T50 would be additionally

Printer-friendly version

Discussion paper 
helpful.

Lines 141-144: could the authors offer a hypothesis to this lack of verifiability?

The hypothesis of proteinaceous material acting as IN is valid. What about polysaccharides? (Dreischmeier et al., 2017)

Line 166: was there any hypothesis associated with the selection of the strains presented in this section?

Size experiments should be compared to (Irish et al., 2019; Wilson et al., 2015) for example. In addition, the Wilson et al., Nature 2015 paper has a $\mathrm{nm}$ parameterization that the authors should include in their discussion of their values.

Lines 184-185: I do not understand how the authors arrived at this conclusion. According to figure 2, the majority of the IN activity was lost between 300 and $100 \mathrm{kDa}$. I would have concluded that the best IN are within that size, not smaller than $100 \mathrm{kDa}$. I agree with the authors nonetheless that there are still IN active material below 100 $\mathrm{kDa}$, but not the most active.

For the discussion to flow, it would be important to explain in line 189 why Erickson came to that conclusion.

The null effect of chemical processing with $\mathrm{O} 3$ and NO2 was somewhat surprising. Based on (Borduas-Dedekind et al., 2019; Gute and Abbatt, 2018; Kunert et al., 2018), I would have expected to see oxidation of the proteinaceous material and thus decrease in IN ability. A discussion involving a hypothesis to the resistance of the strains to oxidation is warranted in light of these studies. Did the authors attempt to extend the exposure to longer times to force a reaction? On a pedantic note, I would argue that ozone exposure of $1 \mathrm{ppm}$ over $4 \mathrm{~h}$ is not equivalent to $200 \mathrm{ppb}$ over $20 \mathrm{~h}$. The experiment was done while bubbling ozone into extracts and there are concentration effects to consider as well as the diffusion of the ozone could affect the chemistry. I would simply omit this sentence and just state the concentration with no mention of

Printer-friendly version

Discussion paper 
equivalence.

Null results are difficult to present. To further substantiate the authors' conclusion, I would recommend that the authors show material that indeed reacted under their $\mathrm{O} 3$ and NO2 conditions. The authors did do a positive control (Lines 205-206) and showing that data would help further support their claim.

Finally, the storage effects were also null results, but did the authors also do a positive control? In any case, these results are very useful for the community.

Figure $\mathrm{S} 1$ arguably belongs in the text. The reproducibility between fungal culture plates is remarkably the largest change observed compared to other treatments such as $\mathrm{O} 3$ and $\mathrm{NO} 2$ exposure. A discussion relating this uncertainty to the other analyses would be important.

Report the weights of the mycelium measured gravimetrically (for example in Table S1).

Is there value in considering the work in the context of food science and cryogenic food storage? Is it more likely that these strains be found in food or in the atmosphere?

Table S1 should present quantitative details. The authors should specify what their criteria is for "IN-active" strains. 1/96 wells? Onset? Temperature range? It would also be useful to add a fourth column with the freezing temperatures (T10 or T50 or T90). Did the authors consider making a parameterization with their data as an upper limit of IN activity of Fusarium species?

6. Conclusion I would revise the statement on line 226 to say that the most IN-active components were actually between $300-100 \mathrm{kDa}$, but that IN activity still remained smaller than $100 \mathrm{kDa}$.

Printer-friendly version

Technical comments - The authors use upper case $\mathrm{Nm}$ which is arguably inconsistent with the literature using lower case nm. See Wex et al., ACP, 2015 - Line 14: "impact" should be replaced by "implication", since the authors did not quantify the water cycle 
or the climate in their experiments. - The short summary is very good indeed! (although I would recommend changing the statement to $300 \mathrm{kDa}$, rather than $100 \mathrm{kDa}$.)

References: Borduas-Dedekind, N., Ossola, R., David, R. O., Boynton, L. S., Weichlinger, V., Kanji, Z. A. and McNeill, K.: Photomineralization mechanism changes the ability of dissolved organic matter to activate cloud droplets and to nucleate ice crystals, Atmospheric Chemistry and Physics Discussions, 1-27, doi:https://doi.org/10.5194/acp-2019-427, 2019.

Dreischmeier, K., Budke, C., Wiehemeier, L., Kottke, T. and Koop, T.: Boreal pollen contain ice-nucleating as well as ice-binding "antifreeze" polysaccharides, Sci. Rep., 7, doi:10.1038/srep41890, 2017.

Gute, E. and Abbatt, J. P. D.: Oxidative Processing Lowers the Ice Nucleation Activity of Birch and Alder Pollen, Geophysical Research Letters, 45(3), 1647-1653, doi:10.1002/2017GL076357, 2018.

Irish, V. E., Hanna, S. J., Xi, Y., Boyer, M., Polishchuk, E., Ahmed, M., Chen, J., Abbatt, J. P. D., Gosselin, M., Chang, R., Miller, L. A. and Bertram, A. K.: Revisiting properties and concentrations of ice-nucleating particles in the sea surface microlayer and bulk seawater in the Canadian Arctic during summer, Atmospheric Chemistry and Physics, 19(11), 7775-7787, doi:https://doi.org/10.5194/acp-19-7775-2019, 2019.

Knopf, D. A., Alpert, P. A. and Wang, B.: The role of organic aerosol in atmospheric ice nucleation: A review, ACS Earth Space Chem., 2(3), 168-202, doi:10.1021/acsearthspacechem.7b00120, 2018.

Kunert, A. T., Lamneck, M., Helleis, F., Pöschl, U., Pöhlker, M. L. and FröhlichNowoisky, J.: Twin-plate Ice Nucleation Assay (TINA) with infrared detection for high-throughput droplet freezing experiments with biological ice nuclei in laboratory and field samples, Atmospheric Measurement Techniques, 11(11), 6327-6337, doi:https://doi.org/10.5194/amt-11-6327-2018, 2018.

Printer-friendly version

Discussion paper 
Petters, M. D. and Wright, T. P.: Revisiting ice nucleation from precipitation samples, Geophysical Research Letters, 42(20), 8758-8766, doi:10.1002/2015GL065733, 2015.

Polen, M., Brubaker, T., Somers, J. and Sullivan, R. C.: Cleaning up our water: reducing interferences from nonhomogeneous freezing of "pure" water in droplet freezing assays of ice-nucleating particles, Atmospheric Measurement Techniques, 11(9), 5315-5334, doi:https://doi.org/10.5194/amt-11-5315-2018, 2018.

Šantl-Temkiv, T., Sahyoun, M., Finster, K., Hartmann, S., Augustin-Bauditz, S., Stratmann, F., Wex, H., Clauss, T., Nielsen, N. W., Sørensen, J. H., Korsholm, U. S., Wick, L. Y. and Karlson, U. G.: Characterization of airborne ice-nucleationactive bacteria and bacterial fragments, Atmospheric Environment, 109, 105-117, doi:10.1016/j.atmosenv.2015.02.060, 2015.

Stopelli, E., Conen, F., Morris, C. E., Herrmann, E., Bukowiecki, N. and Alewell, C.: Ice nucleation active particles are efficiently removed by precipitating clouds, Scientific Reports, 5, 16433, doi:10.1038/srep16433, 2015.

Stopelli, E., Conen, F., Guilbaud, C., Zopfi, J., Alewell, C. and Morris, C. E.: Ice nucleators, bacterial cells and Pseudomonas syringae in precipitation at Jungfraujoch, Biogeosciences, 14(5), 1189-1196, doi:10.5194/bg-14-1189-2017, 2017.

Vali, G.: Revisiting the differential freezing nucleus spectra derived from drop-freezing experiments: methods of calculation, applications, and confidence limits, Atmos. Meas. Tech., 12(2), 1219-1231, doi:https://doi.org/10.5194/amt-12-1219-2019, 2019.

Wilson, T. W., Ladino, L. A., Alpert, P. A., Breckels, M. N., Brooks, I. M., Browse, J., Burrows, S. M., Carslaw, K. S., Huffman, J. A., Judd, C., Kilthau, W. P., Mason, R. H., McFiggans, G., Miller, L. A., Najera, J. J., Polishchuk, E., Rae, S., Schiller, C. L., Si, M., Temprado, J. V., Whale, T. F., Wong, J. P. S., Wurl, O., Yakobi-Hancock, J., Abbatt, J. P. D., Aller, J. Y., Bertram, A. K., Knopf, D. A. and Murray, B. J.: A marine biogenic source

Printer-friendly version

Discussion paper 
of atmospheric ice-nucleating particles, Nature, 525(7568), 234-238, 2015.

Interactive comment on Biogeosciences Discuss., https://doi.org/10.5194/bg-2019-276, 2019.

Interactive

comment 